\title{
CANADIAN CITIES: PAST INTO PRESENT
}

\section{Richard Dennis}

\section{Introduction}

The papers in this special issue address in diverse ways the relationship between past and present in major Canadian cities. Their authors explore points of comparison and contrast, continuities and ruptures between past and present; how the past has constrained or offered opportunities for recent developments; and how it is mobilised in discourses about 'heritage'. They are interested, not only in the histories of cities' built environments or their sociocultural composition, but also in seeing cities as sites and subjects of literary and media production. Their focus is not simply on how the past shapes the present, but also on how our study of past cities is shaped by our current concerns. Our present anxieties about access to affordable housing in cities, our fixation on urban cosmopolitanism, our worries about safety, pollution, congestion and the plight of vulnerable groups all have histories in themselves, but also prompt new ways of interpreting and evaluating past cities. The discovery of new sources, or new ways of accessing old sources, not only changes our knowledge of the past, but also the questions we ask. Several of the papers employ digitized sources and computerised searches in ways that would not have been feasible much more than a decade ago.

Will Smith explores how literary critics and journalists both today and in the past have treated imaginative writing about Toronto, a city for long regarded as bereft of a literary past. In the case of Vancouver, it is not only a literary past but any kind of history that has been elided in a particularly serious case of presentism, as Nicolas Kenny argues in his essay connecting 'forgotten pasts' to 'contested futures'. As Kenny shows, this historical amnesia 
has critical implications in the context of neoliberalism, gentrification and a heritage industry that selectively obscures at the same time as it claims to conserve. Phillip Gordon Mackintosh's focus is on a recurrent theme in the history of modernity, the tension between public and private freedom, in this case the contradictory impulses of facilitating speed and efficiency on city streets and nurturing childhood without confining children to the home. Damaris Rose, Lisa Dillon and Marianne Caron report findings from a major investigation of the housing and homes of 'business girls' across major Canadian cities in the early and midtwentieth century. They show the roots of and parallels with current debates about women's independence and autonomy, set in the context of housing market and affordability constraints. A tiny minority of single women set up homes in purpose-built apartments, a form of metropolitan dwelling that Richard Dennis examines in the final paper in this collection. Apartment-living was strongly opposed or treated with suspicion early in the twentieth century. Today, however, if early apartment buildings have survived at all (and this is a very big 'if'), they are often highly prized, architecturally as 'heritage' and socially as 'domestic', the very qualities they were once thought to lack.

All of the contributors were involved in a conference on 'Canadian Cities: Past Into Present', held at the Institute of the Americas, UCL in Spring 2014. Other papers given on that occasion ranged over urban environmental problems such as air and water pollution, questions of religious and ethno-political identity, and representations of cities in photography, literature and film. The urban past is not of purely antiquarian interest, but nor is it a question of reading off unambiguous 'lessons'. Consciously or unconsciously, we are engaged in a constant dialogue with past peoples and environments, seeking to understand the present in the light of the past, but also (re)reading the past in the light of the present. 